\title{
The genetic basis of developmental stability. V. Inter- and intra-individual character variation
}

\author{
GEOFFREY M. CLARKE* \\ CSIRO Entomology, GPO Box 1700, Canberra, ACT 2601, Australia
}

\begin{abstract}
Examination of levels of inter- and intra-individual variation for a number of characters across 11 invertebrate species revealed a significant concordance of character coefficients of variation among samples within a species, suggesting that some characters are consistently more (or less) variable than others. In addition a significant positive correlation between character $\mathrm{CV}$ and asymmetry values was observed, suggesting that the underlying genetic mechanisms responsible for buffering character development against both external and internal environmental variation are either the same or inter-related. These results are discussed in relation to associations between character variation and individual fitness.
\end{abstract}

Keywords: developmental stability, fitness, fluctuating asymmetry, selection.

\section{Introduction}

Developmental homeostasis refers to those mechanisms responsible for ensuring phenotypic constancy in the face of genetic, environmental and developmental variation (Waddington, 1957). Such homeostasis comprises two often confused components, viz. canalization and developmental stability (Zakharov, 1989). Canalization (Waddington, 1942) refers to processes that buffer development to reduce the amount of potential phenotypic variation that might otherwise result from genetic or environmental variation, whereas developmental stability (Mather, 1953) refers to buffering processes that reduce the variation resulting from developmental accidents (noise). In other words, canalization enhances phenotypic constancy regardless of the underlying genotype or environment whereas developmental stability enhances constancy for a given genotype and environment. In essence, canalization acts to reduce phenotypic variation among individuals whereas developmental stability reduces variation within individuals. Waddington $(1957,1960)$ stresses that the underlying genetic mechanisms for these two components are expected to be different.

The degree of developmental homeostasis of any given character has been hypothesized to be a reflection of the functional importance of the character to the organism (Waddington, 1957). Characters for

*E-mail: geoffc@ento.csiro.au which phenotypic constancy is important in terms of individual fitness will be developmentally less variable (better buffered) than characters for which constancy is less important. In terms of canalization, this hypothesis led Waddington (1957) to propose a form of stabilizing selection, called canalizing selection, which acts to eliminate from the population those genotypes that render developmental pathways for a given character sensitive to genetic and environmental variation. Such a hypothesis introduces the idea that both the degree and the underlying genetic mechanisms of developmental homeostasis are character-dependent such that different characters can be expected to show consistently different levels of canalization and developmental stability. It has long been shown that different characters vary in the extent to which they are canalized (Rendel, 1979) and recent evidence suggests that this is also true for developmental stability (Clarke, 1998). It has been observed that different characters display consistent differences in their levels of stability both within and among individuals and populations, that is, some characters are consistently more (or less) stable than others (Clarke, 1998).

The most commonly used measure of developmental stability has been fluctuating asymmetry (random nondirectional differences between the left and right sides of a bilaterally symmetrical organism), with the degree of fluctuating asymmetry directly reflecting the degree of stability, such that the greater the level of stability the lower the level 
of asymmetry (Van Valen, 1962; Palmer \& Strobeck, 1986). The most informative measure of the degree of canalization is the level of phenotypic variation of a character among individuals within populations. Several authors have used levels of inter-individual morphological variation as an estimate of developmental stability (Eanes, 1978; Fleischer et al., 1983; Mitton, 1978; Mitton \& Grant, 1984); however, as differences in the level of such variation will reflect, among other things, the underlying level of genetic variation affecting the trait, its use as a measure of developmental stability, as defined above, is questionable (but see Mitton, 1993). Similarly, authors have used the level of fluctuating asymmetry as a measure of the degree of canalization (Mather, 1953; Tebb \& Thoday, 1954; Thoday, 1955; Reeve, 1960) although again by definition such an approach is questionable given that it ignores levels of interindividual variation.

Given that both canalization and developmental stability appear to be character-dependent, it is of interest to determine if there is any relationship between the levels of canalization and developmental stability across a range of characters. Are characters which are highly canalized also developmentally more stable than less well canalized characters?

\section{Methods}

\section{Data sets}

All data used come from existing data sets. Fifty samples from 11 invertebrate species are used: Apis cerana, A. mellifera, A. m. capensis, A. m. scutellata (Hymenoptera: Apidae), Chrysopa perla (Neuroptera: Chrysopidae), Heptacarpus brevirostris (Crustacea: Decapoda), Lucilia cuprina (Diptera: Calliphoridae), Solenopsis invicta (Hymenoptera: Formicidae), Tisbe holothuriae (Copepoda: Harpacticoida), Trichocolletes affvenutus (Hymenoptera: Colletidae) and Vespula germanica (Hymenoptera: Vespidae). Details of the colonies, experimental protocols used and characters examined for the generation of these data sets can be found elsewhere (Clarke et al., 1986; Clarke \& McKenzie, 1992; Clarke, 1993a, 1997; Clarke \& Oldroyd, 1996). All characters examined display true fluctuating asymmetry, with no evidence of directional asymmetry, antisymmetry or size-dependence.

\section{Statistical analysis}

The degree of canalization of a character within a sample was estimated by the coefficient of variation
(CV) of mean character size (i.e. $\left.\Sigma\left(L_{i}+R_{i} / 2\right) / N\right)$. Developmental stability of a character was estimated as $\Sigma\left|\log \left(L_{i} / R_{i}\right)\right| / N$. Both the $\mathrm{CV}$ and $\Sigma \mid \log \left(L_{i} \mid\right.$ $\left.R_{i}\right) \mid / N$ are dimensionless thus allowing comparisons between different types of characters (meristic and morphometric) measured on different scales. Kendall's coefficient of concordance $(W)$ was used to test if different characters were consistently different in their CV values among samples within a species. Spearman's rank-order correlation coefficient $\left(r_{\mathrm{S}}\right)$ was used to test for significant correlation between $\mathrm{CV}$ and $\Sigma\left|\log \left(L_{i} / R_{i}\right)\right| / N$ within species. For small samples $(<5), r_{\mathrm{S}}$ is very sensitive to slight variation in rank order between the two variables and requires almost perfect concordance in ranks to achieve significance. If the differences among certain values within each variable are nonsignificant within a sample, then the rankings of these values will be determined by chance and thus the values of $r_{\mathrm{S}}$ will be heterogeneous among samples of the same species when the same characters are examined. As such, within-sample tests for correlation may lack the power to detect any true correlation between the variables for small sample sizes. Combining the data from a number of samples within a species, such that there are multiple combinations of $\mathrm{CV}$ and asymmetry values for each character (as many as there are samples) has the potential to provide greater resolution of any true underlying correlation particularly if there is a high level of concordance of character rankings for each variable among populations.

\section{Results}

Coefficients of variation and asymmetry values for each character in each sample are provided in the Appendix.

There is significant concordance in character rankings based on $\mathrm{CV}$ values among samples for the majority of species (Table 1), that is, if character $\mathrm{X}$ is the least variable (lowest $\mathrm{CV}$ ) in one sample there is a significant tendency for it to be the least variable in all other samples within the species. For the three species displaying no significant concordance among samples, examination of the data revealed either no significant differences between $\mathrm{CV}$ values among characters within each sample (Chrysopa perla) or that only one character was significantly different from all others, with the remaining characters showing no differences among themselves (Tisbe holothuriae, Trichocolletes affvenutus).

There is a significant correlation between $\mathrm{CV}$ and asymmetry values for nine of the 11 species 
Table 1 Results of Kendall's coefficient of concordance $(W)$ testing if character $\mathrm{CV}$ values are consistent among samples, and Spearman's rank correlation coefficient $\left(r_{\mathrm{S}}\right)$ testing for correlation between $\mathrm{CV}$ value and asymmetry value across characters and samples within a species

\begin{tabular}{lcccccc}
\hline Species & $\begin{array}{c}\text { No. of } \\
\text { samples }\end{array}$ & $\begin{array}{c}\text { No. of } \\
\text { characters }\end{array}$ & $W$ & $P$ & $r_{\mathrm{S}}$ & $P$ \\
\hline Apis cerana & 4 & 5 & 0.838 & $<0.01$ & 0.883 & $<0.001$ \\
Apis mellifera & 5 & 6 & 0.914 & $<0.001$ & 0.795 & $<0.001$ \\
A. m. capensis & 6 & 5 & 0.628 & $<0.01$ & 0.563 & $<0.001$ \\
A. m. scutellata & 6 & 5 & 0.878 & $<0.001$ & 0.333 & $<0.05$ \\
Chrysopa perla & 4 & 4 & 0.525 & $\mathrm{NS}$ & 0.241 & $\mathrm{NS}$ \\
Heptacarpus brevirostris & 3 & 5 & 0.956 & $<0.05$ & 0.241 & $\mathrm{NS}$ \\
Lucilia cuprina & 4 & 3 & 1.000 & $<0.05$ & 0.741 & $<0.01$ \\
Solenopsis invicta & 6 & 5 & 0.956 & $<0.001$ & 0.753 & $<0.001$ \\
Tisbe holothuriae & 2 & 5 & 0.550 & $\mathrm{NS}$ & 0.879 & $<0.001$ \\
Trichocolletes affvenutus & 2 & 7 & 0.786 & $\mathrm{NS}$ & 0.640 & $<0.01$ \\
Vespula germanica & 3 & 3 & 1.000 & $<0.05$ & 0.733 & $<0.05$ \\
\hline
\end{tabular}

examined (Table 1), that is, characters displaying low between-individual variation (low $\mathrm{CV}$ ) have a significant tendency to display low within-individual variation (low asymmetry).

\section{Discussion}

The high levels of concordance of character rankings based on $\mathrm{CV}$ values among samples within a species are indicative of underlying differences between characters in the mechanisms responsible for character expression, i.e. they are character-dependent. Such character-dependency is consistent with that observed for the mechanisms underlying developmental stability of these characters within these species (Clarke, 1998). The significant positive correlation between coefficient of variation and asymmetry values suggests that the mechanisms responsible for both inter- and intra-individual variation affect individual characters in the same manner, such that characters which display low levels of inter-individual variation also display relatively low levels of intra-individual variation.

It must be noted that differences in the coefficients of variation among characters are not necessarily indicative of differences in the level of canalization among them, but only of differences in their levels of phenotypic variance. A relatively low $\mathrm{CV}$ may simply reflect reduced levels of genetic variability for a given character compared with a character with a relatively higher CV. It might be expected that characters under a long history of directional or stabilizing selection may have reduced genetic variability, particularly if the character is directly related to individual fitness (Mather, 1973; Falconer, 1981).
However, at least in the case of Apis and Lucilia, the characters examined herein have been shown to have high narrow-sense heritabilities, indicative of appreciable amounts of underlying additive genetic variability (Oldroyd \& Moran, 1983; Clarke \& McKenzie, 1987; Oldroyd et al., 1991). Thus the different $\mathrm{CV}$ values for these characters (range 1.5-11\% for Apis, 6-15\% for Lucilia) at least potentially reflect relative levels of canalization, remembering that canalization mechanisms act to mask underlying genetic variation.

The positive relationship between inter- and intraindividual variation for a given character may have a number of explanations, the simplest of which is that the underlying genetic and molecular mechanisms responsible for the two types of variation are one and the same. It seems plausible to suggest that the mechanisms (and therefore genetic basis) responsible for buffering a given developmental pathway against external environmental variance (canalization), could be equally responsible for buffering the same pathway from internal environmental variance (developmental stability). Differences among characters would reflect either differences in the genes controlling development of each character or differences in the efficiency of the buffering mechanisms themselves, or both. One possible way of testing this hypothesis would be to try to obtain differential responses between inter- and intra-individual variation to some stress. If stress acts to reduce homeostasis mechanisms in general, and the two measures reflect the same underlying process, then it would be expected that both $\mathrm{CV}$ and asymmetry values would increase in response to stress. The early experiments of Waddington (1960) with Drosophila found that 
although phenotypic variance among individuals increased in response to stress the level of asymmetry was either unchanged or reduced. This observation was the major reason for his suggestion that canalization and developmental stability were inherently different phenomena. Within the current study it is possible to compare stressed and unstressed populations within some species. In Tisbe holothuriae inbreeding has been shown to increase asymmetry for four of the five characters examined (Clarke et al., 1986). Examination of the $\mathrm{CV}$ values indicates that inbred individuals have higher values than outbreds for four of five characters of which only two are significantly higher. In Apis mellifera haploid males are significantly more asymmetric than diploid females for all characters (Clarke \& Oldroyd, 1996; Clarke, 1997). Again CV values are consistently higher for all characters in males compared with females, four of which are significantly higher. Similar results are observed for Lucilia cuprina, in which significant increases in asymmetry (Clarke \& McKenzie, 1992) are matched by increases in CV in temperature-stressed populations. Unfortunately, very few studies exist that have directly compared both the response of asymmetry and inter-individual morphological variation in response to stress (but see Zakharov, 1989).

Another possible explanation, related to the first, may be that there are no specific genes or controlling mechanisms responsible for canalization or developmental stability per se but rather that both measures of variation may be reflecting a third unknown character-specific attribute which either directly or indirectly impinges on character development. Possibilities include the level of heterozygosity or coadaptation of the genes controlling individual character expression such that heterozygous or well balanced genotypes are innately better able to buffer character development against environmental perturbation (see Mitton \& Grant, 1984; Palmer \& Strobeck, 1986; Clarke, 1993b for reviews). Any differences between characters would reflect differences in the level of heterozygosity or balance between each set of character genes. Unfortunately, very little is known about the nature of genes responsible for metric character development (Falconer, 1981), but the advent of DNA-based mapping of quantitative trait loci (QTL) may provide valuable insights in this area. Again a concordant response of both measures to stress would be expected.

A third possibility is that the two processes are genetically and mechanistically different both within and between characters as originally postulated by
Waddington (1960). The response of each mechanism to any given stress would depend on the interaction between the genotype and the environmental stress and may or may not be different between characters. The positive relationship between the two processes may reflect a common underlying association between the character and fitness. Characters for which phenotypic constancy is important in terms of fitness (locomotory characters) may be expected to display lower levels of both inter- and intra-individual variation compared with characters unrelated to fitness (see Clarke, 1995). The current data are consistent with this hypothesis. In general within the hymenopteran species examined, wing length consistently displayed the lowest $\mathrm{CV}$ and asymmetry values across all species and the number of hamuli (used in joining fore and hind wings together in flight) displayed the highest $\mathrm{CV}$ and asymmetry values. It can be argued that absolute wing length and wing symmetry is related to flying ability in flying insects. The fact that the number of hamuli varies enormously among hymenopteran species (even among species within the same genus) would argue that the absolute number is relatively unimportant for efficient flight and similarly that absolute symmetry is also of relatively little importance. It is also of interest to note that in general morphometric characters displayed lower $\mathrm{CV}$ and asymmetry values than meristic characters, but this may be because almost all the morphometric characters examined were characters involved in locomotion and thus may be expected to display lower values for the reasons above.

It must be stressed that the hypothesized relationship between inter- and intra-individual variation and fitness only relates to associations between the character under examination and its direct impact on fitness. It does not suggest that $\mathrm{CV}$ or asymmetry values for a performance character should be any more or less closely associated with other estimates of fitness, such as viability or fertility, than nonperformance characters. A recent review by Leung \& Forbes (1996) revealed that although there is a significant negative correlation between character asymmetry and individual fitness across a large number of characters and species, there is no indication that performance characters are any better predictors of conventional fitness than nonperformance characters.

In summary, the genetic basis and mechanisms responsible for buffering character development against both external and internal genetic and environmental variation appear to be both character dependent and inter-related. The exact nature of the 
relationships between these mechanisms remains speculative although potentially reflects an association between levels of character variation and individual fitness.

\section{References}

ClARKe, G. M. 1993a. Patterns of developmental stability in Chrysopa perla L. (Neuroptera: Chrysopidae) in response to environmental pollution. Environ. Entomol., 22, 1362-1366.

CLARKE, G. M. 1993b. The genetic basis of developmental stability. I. Relationships between stability, heterozygosity and genomic coadaptation. Genetica, 89, 15-23.

ClARKE, G. M. 1995. The genetic basis of developmental stability. II. Asymmetry of extreme phenotypes revisited. Am. Nat., 146, 708-725.

CLARKE, G. M. 1997. The genetic basis of developmental stability. III. Haplodiploidy: are males more unstable than females? Evolution, 51, 2019-2026.

ClARKE, G. M. 1998. The genetic basis of developmental stability. IV. Individual and population asymmetry parameters. Heredity, 80, 553-561.

ClARKE, G. M. AND McKENZIE, J. A. 1987. Genetic architecture and adaptation: quantitative analysis of sheep and refuse tip populations of the Australian sheep blowfly, Lucilia cuprina. Aust. J. Biol. Sci., 40, 47-56.

ClARKE, G. M. AND McKENZIE, L. J. 1992. Fluctuating asymmetry as a quality control indicator for insect mass rearing processes. J. Econ. Entomol., 85, 2045-2050.

ClARKE, G. M. AND OLDROYD, B. P. 1996. The genetic basis of developmental stability in Apis mellifera. II. Relationships between character size, asymmetry and singlelocus heterozygosity. Genetica, 97, 211-224.

ClARKe, G. M., BRAND, G. W. AND WHITTEN, M. J. 1986. Fluctuating asymmetry: a technique for measuring developmental stress caused by inbreeding. Aust. J. Biol. Sci., 39, 145-153.

EANES, W. F. 1978. Morphological variance and enzyme heterozygosity in the monarch butterfly. Nature, 276, 263-264.

FALCONER, D. S. 1981. Introduction to Quantitative Genetics, 2nd edn. Longman, London.

FLEISCHER, R. C., JOHNSTON, R. F. AND KLITZ, W. J. 1983. Allozyme heterozygosity and morphological variation in house sparrows. Nature, 304, 628-629.

LEUNG, B. AND FORBES, M. R. 1996. Fluctuating asymmetry in relation to stress and fitness: effects of trait type as revealed by meta-analysis. Ecoscience, 3, 400-413.

MATHER, K. 1953. Genetical control of stability in development. Heredity, 7, 297-336.

MAther, K. 1973. Genetical Structure of Populations. Chapman and Hall, London.

MitTON, J. B. 1978. Relationship between heterozygosity for enzyme loci and variation of morphological characters in natural populations. Nature, 273, 661-662.

mitton, J. в. 1993. Enzyme heterozygosity, metabolism, and developmental stability. Genetica, 89, 47-65.

MITTON, J. B. AND GRANT, M. C. 1984. Associations between protein heterozygosity, growth rate, and developmental homeostasis. Ann. Rev. Ecol. Syst., 15, 479-499.

OLDROYD, B. P. AND MORAN, C. 1983. Heritability of worker characters in the honeybee (Apis mellifera). Aust. J. Biol. Sci., 36, 323-332.

OLDROYD, B., RINDERER, T. AND BUCO, s. 1991. Heritability of morphological characters used to distinguish European and Africanized honeybees. Theor. Appl. Genet., 82, 499-504.

PAlMER, A. R. AND STROBECK, c. 1986. Fluctuating asymmetry: measurement, analysis, patterns. Ann. Rev. Ecol. Syst., 17, 391-421.

REEVE, E. C. R. 1960. Some genetic tests on asymmetry of sternopleural chaeta number in Drosophila. Genet. Res., 1, 151-172.

RENDEL, J. M. 1979. Canalization and selection. In: Thompson J. N. and Thoday J. M. (eds) Quantitative Genetic Variation, pp. 139-156. Academic Press, London.

TEBB, G. AND THODAY, J. M. 1954. Stability in development and relational balance of X-chromosomes in Drosophila melanogaster. Nature, 174, 1109-1110.

THODAY, J. M. 1955. Balance, heterozygosity and developmental stability. Cold Spring Harb. Symp. Quant. Biol., 20, 318-326.

VAN VALEN, L. 1962. A study of fluctuating asymmetry. Evolution, 16, 125-142.

waddington, C. H. 1942. Canalization of development and the inheritance of acquired characters. Nature, 150, $563-565$

waddington, c. H. 1957. The Strategy of the Genes. Macmillan, New York.

WAdDington, C. H. 1960. Experiments on canalizing selection. Genet. Res., 1, 140-150.

ZAKHAROV, v. M. 1989. Future prospects for population phenogenetics. Sov. Sci. Rev. F Physiol. Gen. Biol., 4, $1-79$. 
Appendix

\begin{tabular}{|c|c|c|c|c|c|c|c|c|c|c|c|c|c|c|}
\hline Species/Sample $\dagger$ & Char. & Type $\ddagger$ & CV§ & Asymmetry§ & Species/Sample† & Char. & Typę̋ & CV§ & Asymmetry§ & Species/Sample† & Char. & Typeł & $\mathrm{CV} \S$ & Asymmetry§ \\
\hline $\begin{array}{l}\text { Apis cerana } \\
\text { Male } 1 \text { (47) }\end{array}$ & $\begin{array}{l}1 \\
2 \\
3 \\
4 \\
5 \\
5\end{array}$ & $\begin{array}{l}\mathrm{M} \\
\mathrm{M} \\
\mathrm{M} \\
\mathrm{M} \\
\mathrm{C}\end{array}$ & $\begin{array}{l}2.60(1) \\
2.84(2) \\
3.80(4) \\
3.12(3) \\
7.84(5)\end{array}$ & $\begin{array}{l}0.0095(1) \\
0.0146(3) \\
0.0129(2) \\
0.0191(4) \\
0.0556(5)\end{array}$ & Female 3 (31) & $\begin{array}{l}1 \\
2 \\
3 \\
4 \\
5\end{array}$ & $\begin{array}{l}\mathrm{M} \\
\mathrm{M} \\
\mathrm{M} \\
\mathrm{M} \\
\mathrm{C}\end{array}$ & $\begin{array}{l}2.61(1) \\
4.20(4) \\
3.50(3) \\
3.4(2) \\
6.62(5)\end{array}$ & $\begin{array}{l}0.0065(1) \\
0.0131(3) \\
0.0106(2) \\
0.0230(4) \\
0.0564(5)\end{array}$ & T23.3 (100) & $\begin{array}{l}1 \\
2 \\
3 \\
1 \\
2 \\
3\end{array}$ & $\begin{array}{l}\text { C } \\
\text { C } \\
\text { C } \\
\text { C } \\
\text { C } \\
\text { C }\end{array}$ & $\begin{array}{l}8.34(2) \\
10.93(3) \\
5.55(1) \\
7.51(2) \\
9.93(3) \\
6.07(1)\end{array}$ & $\begin{array}{l}0.1039(2) \\
0.1160(3) \\
0.0659(1) \\
0.0690(2) \\
0.1216(3) \\
0.0532(1)\end{array}$ \\
\hline \multirow{2}{*}{ Female 1 (70) } & $\begin{array}{l}1 \\
2\end{array}$ & $\begin{array}{l}\mathrm{M} \\
\mathrm{M}\end{array}$ & $\begin{array}{l}1.54(1) \\
2.85(2)\end{array}$ & $\begin{array}{l}0.0093(1) \\
0.0096(2)\end{array}$ & \multirow[t]{2}{*}{$\begin{array}{l}\text { Apls. sucueluata } \\
\text { Male 1 (30) }\end{array}$} & $\frac{1}{2}$ & $\begin{array}{l}\mathrm{M} \\
\mathrm{M}\end{array}$ & $\begin{array}{l}2.89(2) \\
3.96(3)\end{array}$ & $\begin{array}{l}0.0076(1) \\
0.0137(3)\end{array}$ & \multirow{3}{*}{$\begin{array}{l}\text { Solenopsis invicta } \\
\text { Colony } 1(40)\end{array}$} & & & & $0.0504(3)$ \\
\hline & $\begin{array}{l}3 \\
4 \\
5\end{array}$ & $\begin{array}{l}\mathrm{M} \\
\mathrm{M}\end{array}$ & $\begin{array}{l}4.38(3) \\
4.53(4) \\
4.85(5)\end{array}$ & $\begin{array}{l}0.0206(3) \\
0.0224(4)\end{array}$ & & $\begin{array}{l}3 \\
4 \\
5\end{array}$ & $\begin{array}{l}\mathrm{M} \\
\mathrm{M}\end{array}$ & $\begin{array}{l}4.13(4) \\
2.87(1)\end{array}$ & $\begin{array}{l}0.0090(2) \\
0.0156(4)\end{array}$ & & $\begin{array}{l}1 \\
3 \\
3\end{array}$ & $\begin{array}{l}\mathrm{M} \\
\mathrm{M}\end{array}$ & $\begin{array}{l}5.09(2) \\
4.75(1)\end{array}$ & $\begin{array}{l}0.0347(2) \\
0.0338(1)\end{array}$ \\
\hline \multirow{4}{*}{ Male 2 (17) } & $\begin{array}{l}5 \\
1\end{array}$ & $\stackrel{\mathrm{M}}{\mathrm{C}}$ & $\begin{array}{l}\begin{array}{r}4.85(5) \\
2.06(1)\end{array} \\
\end{array}$ & $\begin{array}{l}0.0728(5) \\
0.0047(1)\end{array}$ & \multirow{3}{*}{ Female $1(40)$} & $\begin{array}{l}5 \\
1\end{array}$ & ${ }_{\mathrm{M}}^{\mathrm{C}}$ & $\begin{array}{l}8.37(5) \\
2.38(1)\end{array}$ & $\begin{array}{l}0.0614(5) \\
0.0068(1)\end{array}$ & & $\begin{array}{l}4 \\
5\end{array}$ & ${ }_{\mathrm{C}}^{\mathrm{M}}$ & $\begin{array}{l}11.02(5) \\
6.32(3)\end{array}$ & $\begin{array}{l}0.0647(4) \\
0.0822(5)\end{array}$ \\
\hline & 2 & $\mathrm{M}$ & $\begin{array}{l}3.46(3) \\
3.23(3)\end{array}$ & $0.0141(2)$ & & 2 & $\mathrm{M}$ & $\begin{array}{l}4.74(4) \\
.68(2)\end{array}$ & $\begin{array}{l}0.0116(2) \\
0.0116(3)\end{array}$ & Colony 2 (52) & 1 & M & $\begin{array}{l}1.106(4) \\
11.06(4)\end{array}$ & $\begin{array}{l}0.0631(3) \\
0.031\end{array}$ \\
\hline & $\begin{array}{l}3 \\
4 \\
4\end{array}$ & $\stackrel{\mathrm{M}}{\mathrm{M}}$ & $\begin{array}{l}3.23(2) \\
3.65(4)\end{array}$ & $\begin{array}{l}\begin{array}{l}0.0164(3) \\
0.0203(4)\end{array} \\
0.00\end{array}$ & & $\begin{array}{l}3 \\
4\end{array}$ & $\begin{array}{l}\mathrm{M} \\
\mathrm{M}\end{array}$ & $\begin{array}{l}2.68(2) \\
3.42(3)\end{array}$ & $\begin{array}{l}0.01569(3) \\
0.0159(4)\end{array}$ & & $\frac{2}{3}$ & $\begin{array}{l}\mathrm{M} \\
\mathrm{M}\end{array}$ & $\begin{array}{l}5.62(2) \\
5.16(1)\end{array}$ & $\begin{array}{l}0.03070(1) \\
0.0349(2)\end{array}$ \\
\hline & 5 & C & $9.46(5)$ & $0.0606(5)$ & & 5 & C & $7.99(5)$ & $0.0661(5)$ & & 4 & M & 15.78 (5) & 0.0690 (5) \\
\hline Female 2 (41) & $\frac{1}{2}$ & $\begin{array}{l}\mathrm{M} \\
\mathrm{M}\end{array}$ & $\begin{array}{l}\begin{array}{l}1.34(1) \\
2.90(3)\end{array} \\
2.04\end{array}$ & $\begin{array}{l}0.0077 \text { (1) } \\
0.0119(2)\end{array}$ & Male 2 (30) & $\begin{array}{l}1 \\
2\end{array}$ & $\begin{array}{l}\mathrm{M} \\
\mathrm{M}\end{array}$ & $\begin{array}{l}3.46(1) \\
5.26(4)\end{array}$ & $\begin{array}{l}0.00855(1) \\
0.0195(4)\end{array}$ & & $\begin{array}{l}5 \\
1\end{array}$ & ${ }_{M}^{C}$ & $\begin{array}{r}6.71(3) \\
12.82(4)\end{array}$ & $\begin{array}{l}0.0639(4) \\
0.0756(4)\end{array}$ \\
\hline & 3 & M & 3.08 (4) & $0.0154(3)$ & & 3 & $\mathrm{M}$ & $4.68(3)$ & $0.0125(2)$ & Colony $3(14)$ & 2 & ${ }_{M}^{M}$ & $\begin{array}{r}12.82(4) \\
6.02(3)\end{array}$ & $\begin{array}{l}0.0756(4) \\
0.0242(1)\end{array}$ \\
\hline & $\begin{array}{l}4 \\
5\end{array}$ & $\begin{array}{l}\mathrm{M} \\
\mathrm{C}\end{array}$ & $\begin{array}{l}2.85(2) \\
5.68(5)\end{array}$ & $\begin{array}{l}0.0195(4) \\
0.057(5)\end{array}$ & & $\begin{array}{l}4 \\
5\end{array}$ & $\begin{array}{l}\mathrm{M} \\
\mathrm{C}\end{array}$ & $\begin{array}{l}\begin{array}{l}4.03(2) \\
5.97(5)\end{array} \\
\end{array}$ & $\begin{array}{l}0.0162(3) \\
0.0685(5)\end{array}$ & & 3 & M & $\begin{array}{l}4.62(1) \\
1.62\end{array}$ & $\begin{array}{l}0.0455(3) \\
\text { (3) }\end{array}$ \\
\hline $\begin{array}{l}\text { Apis mellifera } \\
\text { (1) } 182)\end{array}$ & & & & & Female 2 (40) & 1 & M & $2.92(1)$ & 0.0073 (1) & Colo & 5 & $\mathrm{C}$ & $5.54(2)$ & $\begin{array}{l}0.0907(5) \\
0.0348(2)\end{array}$ \\
\hline Male $1(82)$ & $\begin{array}{l}1 \\
2\end{array}$ & $\begin{array}{l}\mathrm{M} \\
\mathrm{M}\end{array}$ & $\begin{array}{l}2.45(1) \\
6.93(5)\end{array}$ & $\begin{array}{l}0.0106(1) \\
0.0126(3)\end{array}$ & & 3 & $\begin{array}{l}\mathrm{M} \\
\mathrm{M}\end{array}$ & $\begin{array}{l}3.83(4) \\
3.40(3)\end{array}$ & $\begin{array}{l}0.0 .123(2) \\
0.0141(3)\end{array}$ & Colony 4 (44) & $\frac{1}{2}$ & $\begin{array}{l}\mathrm{M} \\
\mathrm{M}\end{array}$ & $\begin{array}{l}9.23(4) \\
5.82(3)\end{array}$ & $\begin{array}{l}0.0675 \text { (4) } \\
0.0312(1)\end{array}$ \\
\hline & 3 & M & $5.23(4)$ & $0.0167(5)$ & & 4 & $\mathrm{M}$ & $\begin{array}{l}3.35(2) \\
5.56(5)\end{array}$ & 0.0189 (4) & & 3 & M & $3.55(1)$ & $0.0380(2)$ \\
\hline & $\begin{array}{l}4 \\
5\end{array}$ & $\begin{array}{c}\mathrm{M} \\
\mathrm{C}\end{array}$ & $\begin{array}{r}\begin{array}{r}4.23(3) \\
11.94(6)\end{array} \\
\text { (a) }\end{array}$ & $\begin{array}{l}0.0145(4) \\
0.0735(6)\end{array}$ & Male $3(30)$ & $\begin{array}{l}5 \\
1\end{array}$ & $\begin{array}{l}\mathrm{C} \\
\mathrm{M}\end{array}$ & $\begin{array}{l}5.26(5) \\
2.93(1)\end{array}$ & $\begin{array}{l}0.0543(5) \\
0.0072(1)\end{array}$ & & $\begin{array}{l}4 \\
5\end{array}$ & $\begin{array}{l}\mathrm{M} \\
\mathrm{C}\end{array}$ & $\begin{array}{r}15.85(5) \\
5.01(2)\end{array}$ & $\begin{array}{l}0.1057(5) \\
0.0551(3)\end{array}$ \\
\hline & 6 & $\mathrm{M}$ & $2.88(2)$ & 0.0115 (2) & & 2 & $\mathrm{M}$ & $3.80(4)$ & $0.0092(3)$ & Colony 5 (47) & 1 & M & $6.78(4)$ & 0.0714 (3) \\
\hline Female 1 (226) & $\frac{1}{2}$ & $\mathrm{M}$ & $\begin{array}{l}2.40(1) \\
3.83(4)\end{array}$ & $\begin{array}{l}0.0074(1) \\
0.0136(3)\end{array}$ & & $\begin{array}{l}3 \\
4 \\
4\end{array}$ & $\mathrm{M}$ & $\begin{array}{l}3.22(3) \\
3.20(2)\end{array}$ & $\begin{array}{l}0.0084(2) \\
0.0108(4)\end{array}$ & & 2 & & $5.29(2)$ & 0.0317 (2) \\
\hline & $\frac{2}{3}$ & $\begin{array}{l}\mathrm{M} \\
\mathrm{M}\end{array}$ & $\begin{array}{l}3.83(4) \\
4.07(5)\end{array}$ & $\begin{array}{l}0.0136 \text { (3) } \\
0.0147(4)\end{array}$ & & $\begin{array}{l}4 \\
5\end{array}$ & $\begin{array}{l}\mathrm{M} \\
\mathrm{C}\end{array}$ & $\begin{array}{l}3.20(2) \\
6.88(5)\end{array}$ & $\begin{array}{l}0.0108(4) \\
0.0560(5)\end{array}$ & & $\begin{array}{l}3 \\
4\end{array}$ & ${ }_{M}^{M}$ & $\begin{array}{r}3.68(1) \\
14.36(5)\end{array}$ & $\begin{array}{l}0.0287(1) \\
0.078(5)\end{array}$ \\
\hline & $\begin{array}{l}3 \\
4\end{array}$ & $\begin{array}{l}M \\
M\end{array}$ & $\begin{array}{l}4.07(3) \\
2.98(3)\end{array}$ & $\begin{array}{l}0.0147(4) \\
0.0176(5)\end{array}$ & Female $3(40)$ & 1 & $\mathrm{M}$ & $\begin{array}{l}0.37(1) \\
2.37(1)\end{array}$ & $\begin{array}{l}0.0069 \text { (1) } \\
0.0060\end{array}$ & & $\begin{array}{l}4 \\
5\end{array}$ & ${ }_{\mathrm{C}}^{\mathrm{M}}$ & $\begin{array}{r}14.36(5) \\
5.99(3)\end{array}$ & $\begin{array}{l}0.0787(5) \\
0.0861(4)\end{array}$ \\
\hline & 5 & C & $6.87(6)$ & $0.0532(6)$ & & 2 & M & 4.43 (4) & 0.0125 (2) & Colony 6 (40) & 1 & M & $6.04(4)$ & $\begin{array}{l}0.0801(4) \\
0.0575(3)\end{array}$ \\
\hline & 6 & M & $2.87(2)$ & 0.0103 (2) & & $\begin{array}{l}3 \\
4 \\
4\end{array}$ & $\mathrm{M}$ & $3.08(2)$ & 0.0126 (3) & & 2 & M & $3.72(2)$ & $0.0317(2)$ \\
\hline Male 2 (66) & $\begin{array}{l}1 \\
2\end{array}$ & $\begin{array}{l}\mathrm{M} \\
\mathrm{M}\end{array}$ & $\begin{array}{l}2.23(1) \\
3.12(3)\end{array}$ & $\begin{array}{l}0.0070(1) \\
0.0139(3)\end{array}$ & & $\begin{array}{l}4 \\
5\end{array}$ & ${ }_{\mathrm{C}}^{\mathrm{M}}$ & $\begin{array}{l}3.60(3) \\
8.39(5)\end{array}$ & $\begin{array}{l}0.01988(4) \\
0.0558(5)\end{array}$ & & $\begin{array}{l}3 \\
4\end{array}$ & $\begin{array}{l}\mathrm{M} \\
\mathrm{M}\end{array}$ & $\begin{array}{r}2.74(1) \\
10.81(5)\end{array}$ & $\begin{array}{l}0.0218(1) \\
0.1001(5)\end{array}$ \\
\hline & 3 & $M$ & $4.28(5)$ & $\begin{array}{l}0.0149(4) \\
0.0149\end{array}$ & Chrysopa perla & & $e^{2}+2+2$ & 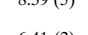 & 0.0030 (ग) & & 5 & ${ }_{\mathrm{C}}^{\mathrm{M}}$ & $5.65(3)$ & $\begin{array}{l}0.1001(5) \\
0.0740(4)\end{array}$ \\
\hline & ${ }_{5}^{4}$ & $\begin{array}{l}\mathrm{M} \\
\mathrm{C}\end{array}$ & $\begin{array}{l}3.34(4) \\
8.66(6)\end{array}$ & $\begin{array}{l}0.0244(5) \\
0.0663(6)\end{array}$ & Site $4(37)$ & $\frac{1}{2}$ & $\begin{array}{l}\mathrm{C} \\
\mathrm{C}\end{array}$ & $\begin{array}{l}6.44(2) \\
6.54(3)\end{array}$ & $\begin{array}{l}0.0489(4) \\
0.0454(3)\end{array}$ & $\begin{array}{l}\text { Tisbe holothuriae } \\
\text { Outbred }(60)\end{array}$ & 1 & $\mathrm{M}$ & $734(2)$ & \\
\hline & 6 & $\mathrm{M}$ & $2.47(2)$ & 0.0078 (2) & & 3 & C & $\begin{array}{l}8.36(4) \\
8.36(1)\end{array}$ & $0.0438(2)$ & 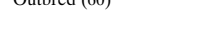 & 2 & C & $7.06(1)$ & $\begin{array}{l}0.0244(1) \\
0.0409(2)\end{array}$ \\
\hline Female 2 (220) & $\frac{1}{2}$ & $\mathrm{M}$ & $\begin{array}{l}2.21(1) \\
403(5)\end{array}$ & $0.0081(1)$ & & 4 & ${ }_{\mathrm{C}}^{\mathrm{C}}$ & $6.01(1)$ & $\begin{array}{l}0.0430(1) \\
0.0515(2)\end{array}$ & & 3 & C & $\begin{array}{l}9.34(3) \\
054(4)\end{array}$ & 0.0584 (4) \\
\hline & $\frac{2}{3}$ & $\begin{array}{l}\mathrm{M} \\
\mathrm{M}\end{array}$ & $\begin{array}{l}\text {. } 3.03(5) \\
3.21(3.5)\end{array}$ & $\begin{array}{l}0.0143(3) \\
0.0170(4)\end{array}$ & Site 2 (35) & $\begin{array}{l}1 \\
2\end{array}$ & ${ }_{\mathrm{C}}^{\mathrm{C}}$ & $\begin{array}{l}6.94(2) \\
7.44(3)\end{array}$ & $\begin{array}{l}0.0515(2) \\
0.0490(1)\end{array}$ & & $\begin{array}{l}4 \\
5\end{array}$ & ${ }_{\mathrm{C}}^{\mathrm{C}} \mathrm{r}-\mathrm{a}-\mathrm{s}$ & $\begin{array}{r}9.54(4) \\
11.78(5)\end{array}$ & $\begin{array}{l}0.0451(3) \\
0.0691(5)\end{array}$ \\
\hline & 4 & $\begin{array}{l}M \\
M\end{array}$ & $3.21(3.5)$ & $\begin{array}{l}0.0192(5) \\
0.017(4)\end{array}$ & & 3 & $\mathrm{c}$ & $8.67(4)$ & $\begin{array}{l}0.0490(1) \\
0.0556(4)\end{array}$ & Inbred (30) & 1 & M & $10.59(2)$ & $\begin{array}{l}0.0691(5) \\
0.0548(1)\end{array}$ \\
\hline & 5 & C & $6.44(6)$ & 0.0605 (6) & & 4 & C & 6.76 (1) & $0.0533(3)$ & & 2 & c & $12.80(4)$ & $0.1016(5)$ \\
\hline & 6 & M & $2.47(2)$ & $0.0100(2)$ & Site $1(49)$ & 1 & C & 8.55 (4) & $0.0468(2)$ & & 3 & c & 10.98 (3) & $0.0622(3)$ \\
\hline Female 3 (75) & $\frac{1}{2}$ & $\mathrm{M}$ & $2.45(1)$ & $\begin{array}{l}0.0089(1) \\
0.0148(3)\end{array}$ & & 2 & ${ }_{\mathrm{C}}^{\mathrm{C}}$ & $\begin{array}{l}8.11(3) \\
804(2)\end{array}$ & $\begin{array}{l}0.0504(3) \\
0.0637(4)\end{array}$ & & $\begin{array}{l}4 \\
5\end{array}$ & ${ }_{\mathrm{C}}^{\mathrm{C}}$ & $\begin{array}{r}7.97(1) \\
1471(5)\end{array}$ & $\begin{array}{l}0.0570(2) \\
0.089(4)\end{array}$ \\
\hline & $\frac{2}{3}$ & $\begin{array}{l}\mathrm{M} \\
\mathrm{M}\end{array}$ & $\begin{array}{l}3.80(5) \\
3.99(5)\end{array}$ & $\begin{array}{l}0.0148(3) \\
0.0170(4)\end{array}$ & & $\begin{array}{l}3 \\
4\end{array}$ & ${ }_{\mathrm{C}}^{\mathrm{C}}+\mathrm{r}-\mathrm{a}$ & $\begin{array}{l}8.04(2) \\
6.91(1)\end{array}$ & $\begin{array}{l}0.0637(4) \\
0.0416(1)\end{array}$ & & 5 & $\mathrm{C}$ & $14.71(5)$ & $0.0839(4)$ \\
\hline & 4 & $\mathrm{M}$ & $3.86(4)$ & $\begin{array}{l}0.0173(5) \\
0.0173(5)\end{array}$ & Site - $1(40)$ & 1 & c & $\begin{array}{l}7.46(3) \\
7.46\end{array}$ & $0.0515(3)$ & Male (17) & 1 & M & $3.36(3)$ & $0.0053(1)$ \\
\hline & $\begin{array}{l}5 \\
6\end{array}$ & $\begin{array}{c}\mathrm{C} \\
\mathrm{M}\end{array}$ & $\begin{array}{l}7.56(6) \\
3.11(2) \\
-\end{array}$ & $\begin{array}{l}0.0537(6) \\
0.0101(2)\end{array}$ & & $\frac{2}{3}$ & ${ }_{\mathrm{C}}^{\mathrm{C}}$ & $\begin{array}{l}5.85(1) \\
7.60(4)\end{array}$ & $\begin{array}{l}0.0552(4) \\
0.0507(2)\end{array}$ & & $\frac{2}{3}$ & ${ }_{M}^{M}$ & $\begin{array}{l}3.38(4) \\
3.09(1)\end{array}$ & $\begin{array}{l}0.0079(3) \\
0.071(2)\end{array}$ \\
\hline Apis m. capensis & & & $3.11(2)$ & & & 4 & C & $6.23(2)$ & $0.0452(1)$ & & 4 & $\mathrm{M}$ & $4.30(5)$ & $0.0101(4)$ \\
\hline Male 1 (31) & $\frac{1}{2}$ & M & $3.64(2)$ & $\begin{array}{l}0.0099(1) \\
0.0185(4)\end{array}$ & $\begin{array}{l}\text { Heptacarpus brevirostris } \\
\text { Site } 1(30)\end{array}$ & 1 & & & $0.0338(3)$ & & 5 & M & 5.56 (6) & 0.0212 (6) \\
\hline & 3 & ${ }_{M}^{M}$ & $\begin{array}{l}4.98(4) \\
3.39(1)\end{array}$ & $\begin{array}{l}0.018(4) \\
0.0126(3)\end{array}$ & site $1(30)$ & $\frac{1}{2}$ & c & $\begin{array}{l}14.31(3) \\
12.71(4)\end{array}$ & $\begin{array}{l}0.0038(3) \\
0.0479(5)\end{array}$ & & $\begin{array}{l}0 \\
7\end{array}$ & ${ }_{\mathrm{C}}^{\mathrm{M}}$ & $3.18(2)$ & $\begin{array}{l}0.0103(5) \\
0.0647(7)\end{array}$ \\
\hline & 4 & $\mathrm{M}$ & 3.75 (3) & $0.0116(2)$ & & 3 & ${ }_{C}$ & $5.28(1)$ & $0.0421(4)$ & Female $(50)$ & 1 & $\mathrm{M}$ & $\begin{array}{l}0.073) \\
2.23\end{array}$ & $0.0647(7)$ \\
\hline & 5 & $\mathrm{C}$ & $7.47(5)$ & $0.0574(5)$ & & 4 & $\mathrm{C}$ & $8.83(3)$ & $0.0274(2)$ & & 2 & ${ }_{M}$ & 作 & $\begin{array}{l}0.0002(2) \\
0.0061(1)\end{array}$ \\
\hline Female 1 (33) & 1 & $\mathrm{M}$ & $2.02(1)$ & $0.0099(2)$ & & & $\mathrm{C}$ & $6.50(2)$ & $0.0257(1)$ & & 3 & $\mathrm{M}_{\mathrm{M}}$ & $227(1)$ & $\begin{array}{l}0.0001(1) \\
0.0084(4)\end{array}$ \\
\hline & 2 & M & $5.50(4)$ & 0.0095 (1) & Site $2(30)$ & 1 & C & $10.56(5)$ & $0.0316(2)$ & & 4 & $\mathrm{M}$ & 2.60 (4) & $\begin{array}{l}0.00064(4) \\
0.0069(3)\end{array}$ \\
\hline & 3 & M & $3.33(2)$ & 0.0133 (3) & & 2 & C & $9.51(4)$ & $0.0554(5)$ & & 5 & M & $2.75(6)$ & 0.0161 (6) \\
\hline & 4 & ${ }_{C}^{M}$ & $\begin{array}{l}3.59(3) \\
8.42(5)\end{array}$ & $\begin{array}{l}0.0367(4) \\
0.05045)\end{array}$ & & 3 & $\mathrm{C}_{\mathrm{C}}$ & $\begin{array}{l}7.19(1) \\
823(3)\end{array}$ & 0.0526 (4) & & 6 & M & $\begin{array}{l}2.62(5) \\
480(7)\end{array}$ & $0.0144(5)$ \\
\hline Male 2 (32) & $\begin{array}{c}5 \\
1\end{array}$ & $\begin{array}{l}\mathrm{C} \\
\mathrm{M}\end{array}$ & $\begin{array}{l}8.42(5) \\
3.17(1)\end{array}$ & $\begin{array}{l}0.0504(5) \\
0.0074(1)\end{array}$ & & $\begin{array}{l}4 \\
5\end{array}$ & ${ }_{\mathrm{C}}^{\mathrm{C}} \mathrm{r}-\mathrm{a}$ & $\begin{array}{l}8.23(3) \\
731(2)\end{array}$ & $\begin{array}{l}0.0482(3) \\
0.0308(1)\end{array}$ & & & & $4.80(7)$ & 0.0426 (7) \\
\hline Male $2(32)$ & $\frac{1}{2}$ & $\begin{array}{l}\mathrm{M} \\
\mathrm{M}\end{array}$ & $\begin{array}{l}5.19(3) \\
5.19(1)\end{array}$ & $\begin{array}{l}0.00 / 4(1) \\
0.0151(4)\end{array}$ & Site $3(30)$ & 1 & $\mathrm{C}$ & $\begin{array}{r}1.31(2) \\
10.64(5)\end{array}$ & $\begin{array}{l}0.03081(1) \\
0.0391(3)\end{array}$ & $\begin{array}{l}\text { Tespula germanca } \\
\text { Male (47) }\end{array}$ & 1 & M & & \\
\hline & 3 & M & $5.38(4)$ & 0.0117 (2) & & 2 & C & $10.01(4)$ & $0.1343(5)$ & & 2 & $\mathrm{M}$ & 4.51 (2) & $\begin{array}{l}0.0104(1) \\
0.0105(2)\end{array}$ \\
\hline & 4 & M & $4.43(2)$ & 0.0121 (3) & & 3 & $\mathrm{C}$ & $6.45(2)$ & $0.0362(2)$ & & 3 & C & $6.66(3)$ & $0.0444(3)$ \\
\hline Female 2(32) & $\begin{array}{l}5 \\
1\end{array}$ & $\stackrel{\mathrm{C}}{\mathrm{M}}$ & $\begin{array}{l}8.98(5) \\
2.34(1)\end{array}$ & $\begin{array}{l}0.0539(5) \\
0.0044(1)\end{array}$ & & $\begin{array}{l}4 \\
5\end{array}$ & ${ }_{\mathrm{C}}^{\mathrm{C}}$ & $\begin{array}{l}7.19(3) \\
5.09(1)\end{array}$ & $\begin{array}{l}0.0422(4) \\
0.0304(1)\end{array}$ & Queen (49) & $\frac{1}{2}$ & $\stackrel{M}{M}$ & $\begin{array}{l}3.07(1) \\
3.66(2)\end{array}$ & $\begin{array}{l}0.0091(2) \\
0.072(1)\end{array}$ \\
\hline & 2 & $\mathrm{M}$ & $3.61(3)$ & $0.0191(2)$ & Lucilia cuprina & & & & $0.0304(1)$ & & 3 & $\mathrm{C}$ & $\begin{array}{l}3.00(2) \\
6.48(3)\end{array}$ & $\begin{array}{l}0.0072(1) \\
0.0348(3)\end{array}$ \\
\hline & $\begin{array}{l}3 \\
4\end{array}$ & $\stackrel{M}{M}$ & $\begin{array}{l}2.70(2) \\
4.03(4)\end{array}$ & $\begin{array}{l}0.0197(3) \\
0.0312(4)\end{array}$ & FB $(100)$ & $\frac{1}{2}$ & ${ }_{\mathrm{C}}^{\mathrm{C}}$ & $\begin{array}{r}8.78(2) \\
1.58(3)\end{array}$ & $\begin{array}{l}0.0845(3) \\
0.0791(2)\end{array}$ & Worker (47) & $\frac{1}{2}$ & $\stackrel{\mathrm{M}}{\mathrm{M}}$ & $5.98(1)$ & $\begin{array}{l}0.0098(1) \\
0.0101(2)\end{array}$ \\
\hline & 5 & ${ }_{C}^{M}$ & $7.00(5)$ & $\begin{array}{l}0.0526(5) \\
0.052(4)\end{array}$ & & 3 & c & $\begin{array}{l}15.58(3) \\
6.48(1)\end{array}$ & $\begin{array}{l}0.0791(2) \\
0.0494(1)\end{array}$ & & 3 & $\mathrm{C}_{\mathrm{C}}^{\mathrm{N}} \mathrm{l}-\mathrm{a}$ & $8.09(3)$ & $\begin{array}{l}0.0101(2) \\
0.0322(3)\end{array}$ \\
\hline Male 3 (31) & 1 & M & $\begin{array}{l}3.63(4) \\
350(1)\end{array}$ & 0.0081 (1) & M15 (100) & 1 & C & 8.15 (2) & $0.1039(2)$ & & & & & \\
\hline & $\begin{array}{l}2 \\
3\end{array}$ & $\begin{array}{l}\mathrm{M} \\
\mathrm{M}\end{array}$ & $\begin{array}{l}3.50(1) \\
3.54(2)\end{array}$ & $\begin{array}{l}0.0106(2) \\
0.0148(3)\end{array}$ & & $\frac{2}{3}$ & ${ }_{\mathrm{C}}^{\mathrm{C}}$ & $\begin{array}{r}10.070(3)(3) \\
6.54(1)\end{array}$ & $\begin{array}{l}0.11600(3) \\
0.0659(1)\end{array}$ & & & & & \\
\hline & $\begin{array}{l}4 \\
5\end{array}$ & $\begin{array}{l}\mathrm{M} \\
\mathrm{C}\end{array}$ & $\begin{array}{l}3.58(3) \\
7.95(5)\end{array}$ & $\begin{array}{l}0.0177(4) \\
0.0610(5)\end{array}$ & & & & & & & & & & \\
\hline
\end{tabular}

$\dagger$ Numbers in parentheses refer to sample sizes.

$\$ \mathrm{M}$, morphometric; $\mathrm{C}$, meristic.

$\S$ Numbers in parentheses refer to character rankings within samples. 